Nig. J. Biotech. Vol. 33 (2017) 24-33

ISSN: 01891731

Available online at

http://www.ajol.info/index.php/njb/index

and www.biotechsocietynigeria.org

DOI: https://dx.doi.org/10.4314/v33i1.4

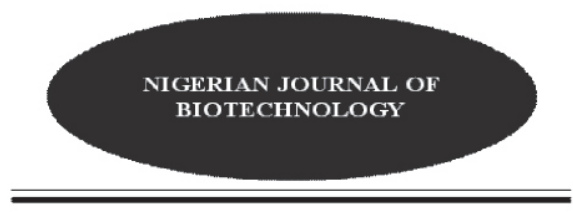

\title{
Effect of detergent and sawdust addition on hydrocarbon reduction and growth of Abelmoschus esculentus L (Okra) in a petroleum-contaminated soil
}

\author{
Tanee, F. B. G. and Jude, K. \\ Department of Plant Science and Biotechnology, Faculty of Science, University of Port \\ Harcourt, Port Harcourt, Nigeria.
}

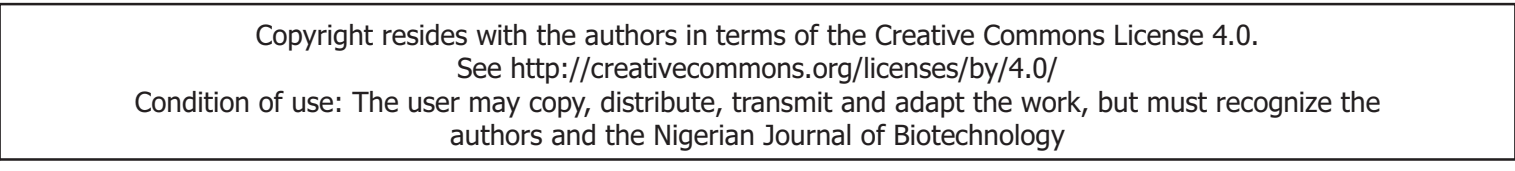

\begin{abstract}
A study to investigate the effect of sawdust and detergent on hydrocarbon reduction and the growth of okra (Abelmoschus esculentus L.) in petroleum polluted soil was carried out. The study was conducted at the Centre for Ecological Studies, University of Port Harcourt. Bonny light crude $(300 \mathrm{ml})$ was used to pollute $10 \mathrm{~kg}$ soil. Detergent $(20 \mathrm{~g})$, sawdust $(200 \mathrm{~g})$ and sawdust: detergent ( $200 \mathrm{~g}: \mathbf{2 0} \mathrm{g}$ ) were used as the amendment materials alongside a control (pollution but un-remediated) arranged in a completely randomized design of 12 replications. After 30 days post-amendment, 3 seeds of okra (var: V35-45 days) were grown in each treatment pot for 6 weeks. Soil Total Hydrocarbon Content (THC) and okra growth performance (shoot length, leaf number, root length, total fresh weight, dry weight, leaf area and leaf area ratio) were analyzed. Results showed significant $(p=0.05)$ reductions in THC of $44.23 \%, 26.5 \%, 70.80 \%$ and $10.79 \%$, in detergent $(20 \mathrm{~g})$, sawdust $(200 \mathrm{~g})$, sawdust $(200 \mathrm{~g})$ + detergent $(20 \mathrm{~g})$ and control, respectively. Improved growth performances of okra were observed in the amended soil as compared to the control. Okra growth performance was in the order of: $200 \mathrm{~g}$ sawdust $+20 \mathrm{~g}$ detergent combination $>\mathbf{2 0 0} \mathrm{g}$ sawdust $>\mathbf{2 0} \mathrm{g}$ detergent. This implies that these two materials are good bio-stimulation materials especially when used in combined form for THC reduction and growth of okra.
\end{abstract}

Keywords: Abelmoschus esculentus L., contamination, crude oil, sawdust, total hydrocarbon content

Correspondence: franklin.tanee@uniport.edu.ng; keayiabaridojude@yahoo.com

\section{Introduction}

The continual changes occurring in the natural environment could be man-made or natural (Dacko and Dacko, 2009; Anyanwu et al. 2014). Man exploits the resources of the environment for his personal benefits and as a result causes alterations in the natural balance of the ecosystem (Goodwin et al., 2008). These changes or alterations caused by the interactions between man and his immediate environment might introduce substances into the environment which in most cases may be undesirable to man and other living organisms (Evelyn and Tyav, 2013). Pollution appears to be one of the environmental problems plaguing human existence on earth. Pollution occurs and affects every aspect of the environment such as land, water and air.

Oil pollution is a serious multi-dimensional environmental problem in Nigeria as its impact on the entire ecosystem cannot be over-emphasized (Tanee and Albert, 2015). Various activities of the oil industries (crude oil exploration, refining, transporting and marketing) in addition to artisanal refining and oil theft have resulted in many oil spills and other oil discharges into the environment. The effects of these activities have been reported to be disastrous to the ecosystems and thus become an issue to the living organisms of contaminated areas, firms or organizations participating in oil prospects and exploration.

(Ambituuni et al., 2014). Wilcox, (2013) reported that crude oil and its by-products are the most important organic pollutants of land and water in 
Nigeria. Crude oil or petroleum hydrocarbon contamination affects the environment in many ways. Such include: disruptions of natural equilibrium between the living species and their natural environment (Das and Chandran, 2010); contamination of surface and groundwaters (Balasubramaniam et al., 2007); stunted growth and death of plants (Anyanwu and Tanee, 2008); reduction in species diversity (Tanee and Albert, 2015); alteration of physical and chemical status of soil with subsequent abandonment of such land (Kibblewhite et al., 2008; Gighi et al., 2012) and; negative effect on animals and human health (Abowei, 1996; Chekroun et al., 2014).

Hydrocarbon contamination has become a critical environmental issue (Wang et al. 2010; Zhu et al. 2010), due to its immobilization and accumulation (Martínez-Jerónimo et al., 2008), and is now seriously affecting the safety of ecosystems and human health (Liste and Felgentreu, 2006).

Thus, the remediation of contaminated soils has become a worldwide concern (Euliss et al. 2008). Remediation of petroleum-contaminated systems could be achieved by either physical/mechanical (e.g excavation, burning); chemical (detergent, surfactant, degreaser), and biological (bioremediation) methods (Okoh, 2006). The method to be adopted for the remediation of a polluted site depends on the circumstances and how suitable or efficient the method is, in each case. However, most of these methods have some drawbacks in completely remediating hydrocarbon contaminated soil. Among the techniques used for ameliorating or remediating crude oil polluted soils, bioremediation (e.g biostimulation) and chemical remediation (e.g. use of detergent) are effective in reducing the impact of crude oil on contaminated sites, although they have their limitations (Kumar et al., 2011).

Biostimulation is a bioremediation strategy that has to do with the addition of materials to stimulate the growth of indigenous microorganisms (Kumar and Gopal, 2015). Input of large quantities of carbon sources such as crude oil, used lubricating oil, and diesel oil tends to result in a rapid depletion of the available pools of major inorganic nutrients such as $\mathrm{N}$ and $\mathrm{P}$. Hence, the addition of nutrients, either organic or inorganic, will replenish the soil with these nutrients and enhances the activities of indigenous microbes.

The concept of biostimulation is that, by adding more nutrients, microorganisms replicate, increase in number and grow rapidly and thus increase the rate of biodegradation (Thieman and Palladino 2009). Addition of detergent to the oil contaminated soil aids to demulsify the hydrocarbon hence increase the rate of remediation process (Millioli et al., 2009; Couto et al., 2010).

This study is carried out to compare the effect of sawdust and detergent in the biostimulation of petroleum contaminated soil for growth of okra. It is expected that results obtained from this study will give us insight on other suitable methods for ameliorating crude oil contaminated soil for enhanced growth of plants.

\section{Materials and methods}

Experimental site

The experiment was conducted at University of Port Harcourt, Choba, Rivers State of Nigeria. University of Port Harcourt is located on a GPS between Latitude $4^{\circ} \mathrm{N}$ and $5^{\circ} \mathrm{N}$, and Longitude $6^{\circ} \mathrm{E}$ and $7^{\circ} \mathrm{E}$. The experimental site was the open field at the Centre for Ecological Studies of the Department of Plant Science and Biotechnology, behind Faculty of Science Multipurpose Building Complex, University Park.

The mean precipitation (rainfall) for the area is about $2500 \mathrm{~mm} /$ year; while the minimum and maximum temperatures were $25^{\circ} \mathrm{C}$ and $35^{\circ} \mathrm{C}$.

\section{Soil collection and contamination}

Soil was collected from a demonstration farm within the university environment for the experiment. Loamy soil was collected at the surface with a spade. Plant particles were removed and the soils thoroughly mix to homogeneity. The method of Tanee and Jude (2017) was used for the pollution application in which $10 \mathrm{~kg}$ of soil was weighed into each perforated experimental bag. Each bag filled with soil was artificially polluted with $300 \mathrm{ml}$ of bonny light crude oil obtained from Port Harcourt Refinery Company, Eleme. A total of 48 bags filled with experimental soil were used for the experiment. The crude oil was thoroughly mixed with the soil. The set up was allowed for 2 weeks for full acclimatization of the oil with the soil under natural environmental (climatic) conditions of sunshine, rainfall, relative humidity and temperature.

\section{Addition of Amendments}

Detergent (brand name: Zip) bought from Eleme market and sawdust obtained from timber mill Rumuosi were applied as the amendment materials according to the method of Jude and Tanee (2016b). The chemical ingredients of the detergent used are surfactant, enzymes, photo bleach, optical brightening agent, builder, perfume and anti-redeposition agent. The concentration levels (amounts) of sawdust and detergent used as amendment were as follows:

T1: $10 \mathrm{~kg}$ soil $+300 \mathrm{ml}$ crude $+20 \mathrm{~g}$ detergent), T2: $10 \mathrm{~kg}$ soil $+300 \mathrm{ml}$ crude $+200 \mathrm{~g}$ sawdust, T3: $10 \mathrm{~kg}$ soil $+300 \mathrm{ml}$ crude $+200 \mathrm{~g}$ sawdust $+20 \mathrm{~g}$ detergent), 
T4: $10 \mathrm{~kg}$ soil $+300 \mathrm{ml}$ crude oil (Control).

The amendments were thoroughly mixed to obtain a uniform mixture. The amendment set-up was allowed for 30 days before planting of the okra.

\section{Planting of Okra}

Okra (Abelmoschus esculentus L) (var: V3545 days) obtained from the Centre for Ecological Studies of the University of Port Harcourt, Rivers State, Nigeria were planted after 30 days of amendment addition. The okra seeds were planted in the experimental bags at the rate of five seeds per bag at the depth of $4 \mathrm{~cm}$. After two weeks of planting, the seedlings were thinned to three (3) per bag after germination. The growth performance of the test plant (okra) was monitored for 6 weeks using some selected growth parameters.

\section{Determination of Total Hydrocarbon content and okragrowth parameters}

The Soxhlet Extraction Method (APHA, 1995) was used for the determination of Total Hydrocarbon Content of the treatment soils. The percentage reduction in THC was calculated using the formula:

$\% \mathrm{THC}$ reduction $=\frac{\text { initial value }- \text { final value }}{\text { Initial value }} \times \frac{100}{1}$

Selected plant growth parameters were investigated. These include germination percentage, shoot length (plant height), number of leaf, leaf area, root length, total fresh weight, total dry weight and leaf area ratio (LAR). These parameters were determined at 2 week interval for 6 weeks with the exception of germination percentage which was determined by counting the number of seedlings that germinated within 5 days after planting.

Germination percentage was calculated as:

$\%$ Germination $=\frac{\text { number of seeds that germinated per pot }}{\text { number of seeds planted per pot }} \times \frac{100}{1}$

Shoot length determination was done by measuring the shoot of the plants in the bags from the soil level to the terminal bud using a meter rule. Average mean shoot length of the plant was calculated. The leaf number count was done by counting the leaves, taking into consideration all leaves for each plant in the experimental pot.

Using the destructive method 4 replicates
( 4 bags planted with okra of each treatment) were harvested. The poly bags were shaken in order for the plants to lose grip, and to make the removal of the plants easier. The plants were harvested by destroying the bags, scattering the soil and the plants in the poly bags were gently and carefully removed to ensure they were intact without destroying the roots. Using an electronic weighing balance Model EK5350, the total fresh weights of the plants (per pot) were determined by weighing the whole plants in each treatment pots immediately after harvest and the values obtained were recorded.

The root length was determined by using metre rule calibrated in centimetre $(\mathrm{cm})$. Lengths of three longest roots on each plant sampled/bag were measured $(\mathrm{cm})$ and average values calculated were recorded.

Total dry weight was determined after ovendrying for a period of $48 \mathrm{hrs}$ at $75^{\circ} \mathrm{C}$. The dried sampled plants were then weighed on an electronic weighing balance Model HX-Z232 to obtain the weights.

The formula: Leaf area (LA) $=0.89 \times$ Length of the leaf $\times$ width of the leaf (broadest part) and 0.89 as a constant (Asoegwu, 1988) was used for the calculation of leaf area and the total leaf area was calculated.

The leaf area ratio was calculated using the formula Leaf Area Ratio $($ LAR $)=\frac{\text { Total leaf area }}{\text { Total dryweight }}$

\section{Statistical evaluation}

From the data generated, means and standard mean error (SEM) were calculated. The data were further analyzed using Analysis of variance (ANOVA) and Least Significant Difference (LSD) tools according to SPSS data analysis package (2014 version). The results were presented in graphs with difference superscripts indicating significant difference @ $\mathrm{P}=$ 0.05 .

\section{Results}

Soil Total Hydrocarbon content (THC)

The result for the total hydrocarbon content (THC) of the soil is presented in Fig 1. The result showed a significant $(p=0.05)$ reduction in the THC content in all the treatments with T3 (amended with a combination of sawdust and detergent) having the highest percentage reduction. The least Total Hydrocarbon Content (THC) reduction was observed in control (unremediated soil). 


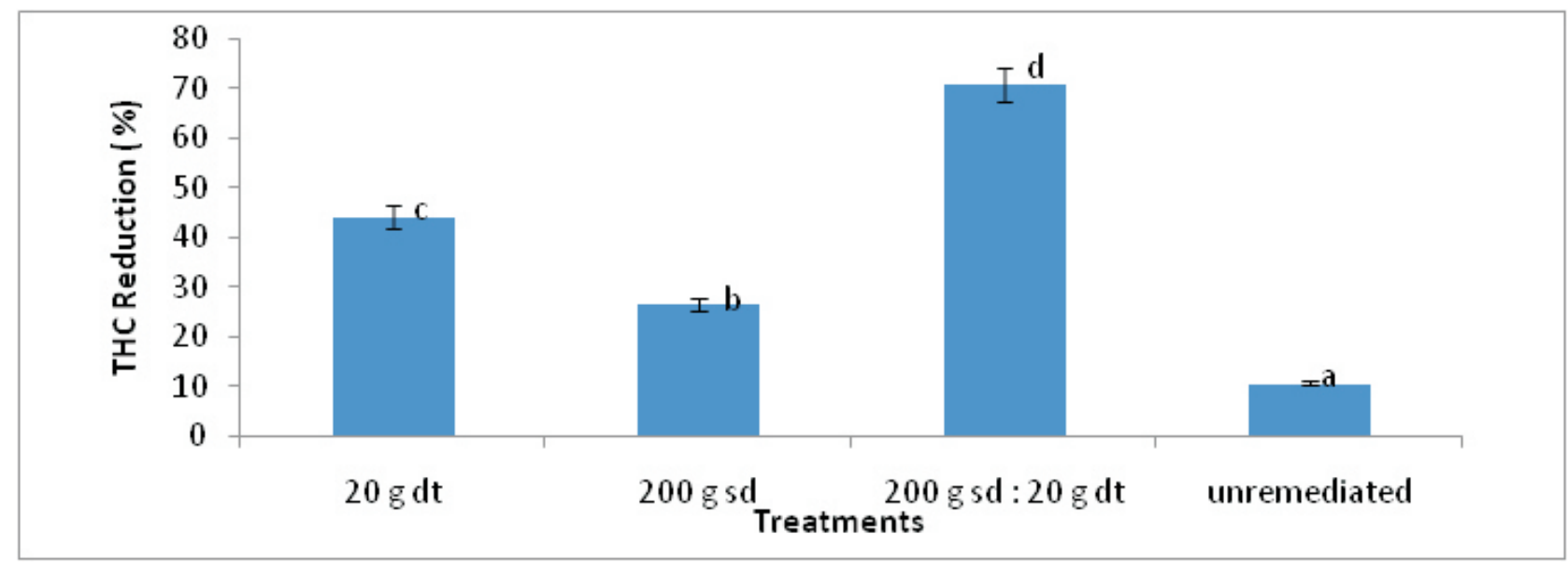

Fig.1: Percentage Reduction in THC in the different treatments

Plant Growth Performance

It was observed that soil amended with Sawdust + detergent combination amendment showed a very high rate of germination as compared to the other treatments (Fig. 2). This was followed by the sawdust single amendment treatment. Detergent (20 g) amended and unremediated (control) treatments recorded below $50 \%$ germination.

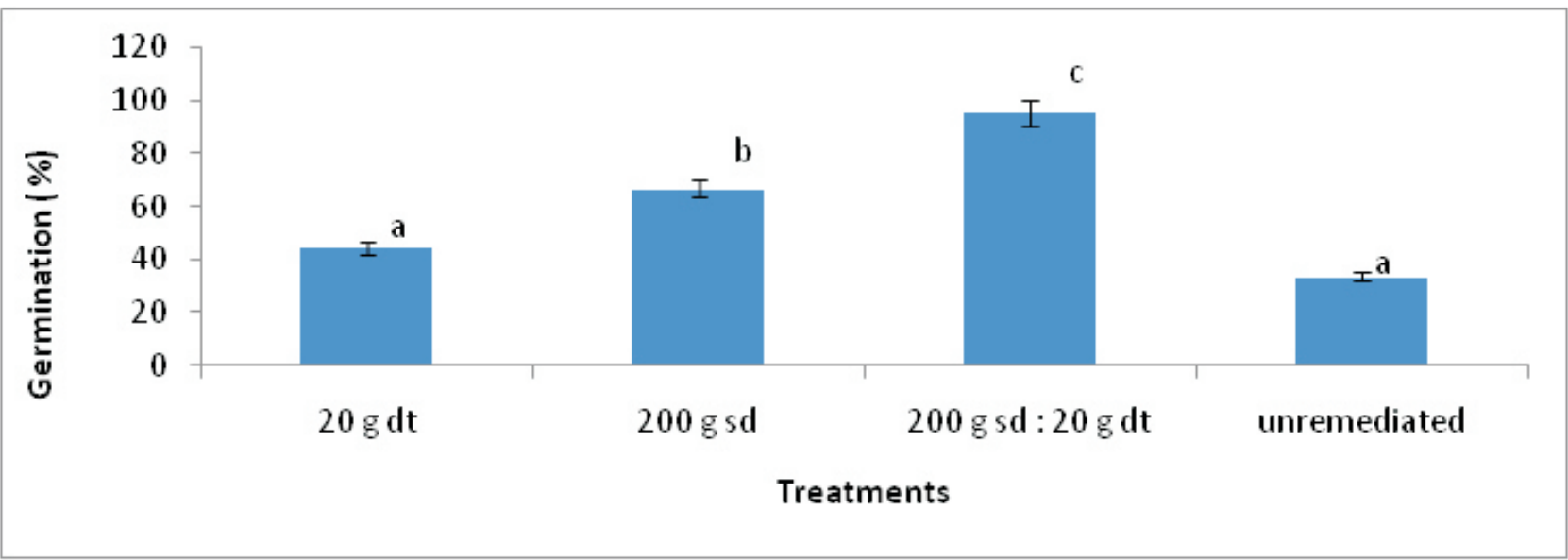

Fig.2: Percentage Germination of Okra in the different treatments.

Shoot length and leaf number between treatments show significant increment $(p=0.05)$ in the combined treatment of sawdust and detergent than the other treatment options. The un-amended soil (control) recorded the least. At 6 WAP, there was no significant difference between $200 \mathrm{~g}$ sawdust single treatment and $200 \mathrm{~g}+20 \mathrm{~g}$ detergent combined treatment while $20 \mathrm{~g}$ detergent treatment and unremediated soil recorded lower values in the shoot length but there was significant difference in the leaf number between the treatments in the order of $20 \mathrm{~g}+200 \mathrm{~g}$ sawdust $>200 \mathrm{~g}$ sawdust $>20 \mathrm{~g}$ detergent $>$ unremediated soil (Table 1). Results show significant reduction in the leaf area in all the treatment options from the 4 WAP to the 6 WAP. Between treatments, the combined treatment of sawdust and detergent recorded the highest $(P=0.05)$ leaf area from 2 WAP to 6 WAP (Table 1 ). 
Table 1: Shoot Length $(\mathrm{cm})$, leaf number and leaf area of okra in the different treatments

\begin{tabular}{|c|c|c|c|c|c|c|c|c|c|}
\hline \multirow{3}{*}{$\begin{array}{l}\text { Amendment } \\
\text { treatments }\end{array}$} & \multicolumn{9}{|c|}{ Weeks After Planting (WAP) } \\
\hline & \multicolumn{3}{|c|}{2 WAP } & \multicolumn{3}{|c|}{4 WAP } & \multicolumn{3}{|c|}{6 WAP } \\
\hline & $\begin{array}{l}\text { Shoot } \\
\text { length } \\
\text { (cm) }\end{array}$ & $\begin{array}{l}\text { Leaf } \\
\text { number }\end{array}$ & $\begin{array}{l}\text { Leaf } \\
\text { area } \\
\left(\mathrm{cm}^{2}\right)\end{array}$ & $\begin{array}{l}\text { Shoot } \\
\text { length } \\
\text { (cm) }\end{array}$ & $\begin{array}{l}\text { Leaf } \\
\text { number }\end{array}$ & $\begin{array}{l}\text { Leaf area } \\
\left(\mathrm{cm}^{2}\right)\end{array}$ & $\begin{array}{l}\text { Shoot } \\
\text { length } \\
(\mathrm{cm})\end{array}$ & $\begin{array}{l}\text { Leaf } \\
\text { number }\end{array}$ & $\begin{array}{l}\text { Leaf area } \\
\left(\mathrm{cm}^{2}\right)\end{array}$ \\
\hline $\begin{array}{l}20 \mathrm{~g} \\
\text { detergent }\end{array}$ & $2.6 \pm 0.01^{b}$ & $2.14 \pm 0.03^{b}$ & $6.21 \pm 2.3^{b}$ & $5.03 \pm 0.02^{b}$ & $4.33 \pm 0.03^{b}$ & $12.00 \pm 1.8^{b}$ & $5.43 \pm 0.1^{b}$ & $2.83 \pm 0.2^{b}$ & $7.87 \pm 1.5^{b}$ \\
\hline $\begin{array}{l}200 \mathrm{~g} \\
\text { sawdust }\end{array}$ & $3.1 \pm 0.02^{b}$ & $2.1 \pm 0.3^{b}$ & $3.91 \pm 1.4^{\mathrm{a}}$ & $6.3 \pm 0.04^{c}$ & $4.00 \pm 0.5^{b}$ & $7.80 \pm 0.9^{\mathrm{a}}$ & $6.43 \pm 0.1^{\text {bc }}$ & $3.6 \pm 1.1^{\mathrm{c}}$ & $8.61 \pm 2.1^{b}$ \\
\hline $\begin{array}{l}200 \mathrm{~g} \\
\text { sawdust + } 20 \\
\text { g detergent }\end{array}$ & $3.49 \pm 0.4^{b}$ & $3.16 \pm 1.2^{c}$ & $5.77 \pm 2.6^{\mathrm{b}}$ & $6.97 \pm 0.1^{c}$ & $6.33 \pm 0.6^{c}$ & $11.30 \pm 1.6^{b}$ & $7.29 \pm 0.2^{c}$ & $5.33 \pm 0.9^{d}$ & $10.76 \pm 2.1^{c}$ \\
\hline $\begin{array}{l}\text { Unremediated } \\
\text { soil }\end{array}$ & $1.25 \pm 0.1^{\mathrm{a}}$ & $1.1 \pm 0.01^{\mathrm{a}}$ & $3.32 \pm 0.8^{\mathrm{a}}$ & $2.53 \pm 0.1^{\mathrm{a}}$ & $2.00 \pm 0.02^{\mathrm{a}}$ & $6.70 \pm 1.9^{\mathrm{a}}$ & $3.4 \pm 0.2^{\mathrm{a}}$ & $2.16 \pm 0.02^{\mathrm{a}}$ & $4.71 \pm 1.1^{\mathrm{a}}$ \\
\hline
\end{tabular}

Different superscripts within column represent significant difference @ $(p=0.05)$

There was a progressive increase in the root length of okra in all the treatment options from the 2 WAP to 6 WAP. At the termination of the experiment (6 WAP), $200 \mathrm{~g}$ sawdust single treatment option recorded the highest $(P=0.05)$ root length, followed by the sawdust + detergent (combined) and the unremediated (control) recording the least (Table 2).

Table 2: Root Length $(\mathrm{cm})$ of okra in the different treatments

\begin{tabular}{llll}
\hline Amendment treatments & Weeks After Planting & (WAP) & \\
\hline & 2WAP & 4WAP & 6WAP \\
20 g detergent & $1.92 \pm 0.09^{\mathrm{a}}$ & $3.77 \pm 1.1^{\mathrm{a}}$ & $4.43 \pm 1.0^{\mathrm{a}}$ \\
$200 \mathrm{~g}$ sawdust & $4.22 \pm 0.9^{\mathrm{b}}$ & $9.33 \pm 1.3^{\mathrm{c}}$ & $10.20 \pm 2.1^{\mathrm{c}}$ \\
$200 \mathrm{~g}$ sawdust $+20 \mathrm{~g}$ detergent & $3.31 \pm 1.0^{\mathrm{b}}$ & $6.80 \pm 2.0^{\mathrm{b}}$ & $8.15 \pm 2.1^{\mathrm{b}}$ \\
Unremediated & $1.21 \pm 0.6^{\mathrm{a}}$ & $3.00 \pm 0.8^{\mathrm{a}}$ & $3.14 \pm 0.3^{\mathrm{a}}$ \\
\hline
\end{tabular}

Different superscripts within column represent significant difference @ $(p=0.05)$

The results of the fresh weight and Total dry weight showed that the amended soil showed an improvement in the fresh weight and dry weight of okra as compared with the control (un-amended) soil. It was also observed that combining sawdust and detergent had a greater positive impact $(P=$ 0.05) than the other treatments and control. Although, at 6 WAP, there was no significant difference in both total fresh and dry weights between $200 \mathrm{~g}$ sawdust treatment and $20 \mathrm{~g}$ detergent treatment (Table 3 ). A reversed result trend was observed in the leaf area ratio (LAR) in which there was a progressive decrease in LAR with time in all the treatment options. Significant difference $(P=0.05)$ was observed at 2 WAP between the treatments; with the control (unremediated) treatment taking the lead and the $20 \mathrm{~g}$ detergent recording the least.

At the termination of the experiment ( $6 \mathrm{WAP}$ ), there was a drop in the LAR in all the treatments with no significant difference between them (Table 4). 
Table 3: Total biomass (fresh weight and dry weight) ( $\mathrm{g}$ ) of okra in the different treatments

\begin{tabular}{|c|c|c|c|c|c|c|}
\hline \multirow{3}{*}{$\begin{array}{l}\text { Amendment } \\
\text { treatments }\end{array}$} & \multicolumn{6}{|c|}{ Weeks After Planting (WAP) } \\
\hline & \multicolumn{2}{|l|}{2 WAP } & \multicolumn{2}{|l|}{4 WAP } & \multicolumn{2}{|l|}{6 WAP } \\
\hline & Fresh & Dry & Fresh & Dry & Fresh & Dry \\
\hline $20 \mathrm{~g}$ detergent & $0.58 \pm 0.01^{\mathrm{b}}$ & $0.14 \pm 0.01^{\mathrm{b}}$ & $1.26 \pm 0.01^{\mathrm{b}}$ & $0.26 \pm 0.01^{\mathrm{b}}$ & $1.38 \pm 0.01^{\mathrm{b}}$ & $0.28 \pm 0.03^{b}$ \\
\hline $200 \mathrm{~g}$ sawdust & $0.62 \pm 0.01^{\mathrm{b}}$ & $0.11 \pm 0.01^{\mathrm{b}}$ & $1.17 \pm 0.1^{\mathrm{b}}$ & $0.23 \pm 0.02^{\mathrm{b}}$ & $1.40 \pm 0.02^{b}$ & $0.26 \pm 0.02^{b}$ \\
\hline $\begin{array}{l}200 \text { g sawdust }+20 \\
\text { g detergent }\end{array}$ & $1.11 \pm 0.01^{\mathrm{c}}$ & $0.13 \pm 0.00^{\mathrm{b}}$ & $2.54 \pm 0.02^{c}$ & $0.30 \pm 0.01^{\mathrm{c}}$ & $1.92 \pm 0.04^{c}$ & $0.38 \pm 0.01^{\mathrm{c}}$ \\
\hline Unremediated & $0.31 \pm 0.01^{\mathrm{a}}$ & $0.05 \pm 0.01^{\mathrm{a}}$ & $0.58 \pm 0.01^{\mathrm{a}}$ & $0.14 \pm 0.00^{\mathrm{a}}$ & $0.48 \pm 0.01^{\mathrm{a}}$ & $0.20 \pm 0.00^{\mathrm{a}}$ \\
\hline
\end{tabular}

Different superscripts within column represent significant difference @ $(p=0.05)$

Table 4: Leaf Area Ratio $(\mathrm{cm} 2 / \mathrm{g})$ of okra in the different treatments

\begin{tabular}{llll}
\hline Amendment treatments & Weeks After Planting (WAP) & \\
\hline & 2 WAP & 4 WAP & 6 WAP \\
$20 \mathrm{~g}$ detergent & $44.36 \pm 3.7^{\mathrm{b}}$ & $46.15 \pm 6.0^{\mathrm{b}}$ & $28.11 \pm 3.4^{\mathrm{a}}$ \\
$200 \mathrm{~g}$ sawdust & $35.55 \pm 4.1^{\mathrm{a}}$ & $33.91 \pm 2.9^{\mathrm{a}}$ & $25.42 \pm 2.6^{\mathrm{a}}$ \\
$200 \mathrm{~g}$ sawdust $+20 \mathrm{~g}$ detergent & $44.39 \pm 2.5^{\mathrm{b}}$ & $37.67 \pm 2.3^{\mathrm{a}}$ & $28.32 \pm 3.0^{\mathrm{a}}$ \\
Unremediated & $66.4 \pm 4.1^{\mathrm{c}}$ & $47.86 \pm 3.2^{\mathrm{b}}$ & $23.55 \pm 2.2^{\mathrm{a}}$ \\
\hline
\end{tabular}

Different superscripts within column represent significant difference $@(p=0.05)$

\section{Discussion}

Different biostimulation methods have been proposed by researchers for the remediation of petroleum contaminated sites. The suitability of any method depends on a number of factors such as type of oil, season of spill, amount of spill, types of ecosystem and the environmental factors prevailing in that ecosystem. The suitability of sawdust and detergent in the remediation of hydrocarbon contamination tropical soil of the Niger Delta was confirmed by the decrease in Total Hydrocarbon Content $(\mathrm{THC})$ in all the treatments.

The highest percentage (\%) reduction of THC in soil was observed in treatment amended with $200 \mathrm{~g}$ sawdust and $20 \mathrm{~g}$ detergent (combined). This is understandable since sawdust is an absorbent ((Pala et al., 2005; Trejo-Hernandez, et al., 2006) as well as containing nutrients (high in organic matter) needed for microbial growth coupled with the demulsification of crude oil by the detergent (Couto et al., 2010).

The sawdust supplied nutrients which are always limited in a crude oil polluted soil (Akujobi et al., 2011) to energize the hydrocarbon degrading microbes while the detergent desorbs the hydrocarbon and provides enough surface area for the microbe to degrade. Hence the combination of these factors might have contributed to the highest rate of hydrocarbon degradation in the combined treatment as compared to other treatments.

Results also show significance reductions of THC in the other amendment options (200 g sawdust and $20 \mathrm{~g}$ detergent single treatments) when compare with the control. This suggests the abilities of sawdust and detergent to reduce hydrocarbon in petroleum polluted soil. The use of sawdust in crude oil remediation has been reported by Akonye and Onwudiwe, (2004); Boodoosingh et al., (2007) and Tanee and Albert, (2011) while that of detergent has been reported by Millioli et al., (2009) and Jude and Tanee (2016a).

The low hydrocarbon degradation in the control soil (without amendment) confirms the toxicity of crude oil to soil microbial degradation (Ogbo, 2009). Crude oil blocked the air pores (Essien and John, 2010) and water pores of soil (hydrophobic). This reduces water holding capacity and aeration in the soil (Abosede, 2013) depriving the soil of oxygen and water; thus affecting the soil-water and soil-air relations for efficient hydrocarbon degradation.

Results showed a significance increase in germination rate in $200 \mathrm{~g}$ sawdust $+20 \mathrm{~g}$ detergent treatment followed by $200 \mathrm{~g}$ sawdust treatment and recording the least at $20 \mathrm{~g}$ detergent and control. The reduction in hydrocarbon toxicity and modification of 
the soil chemical properties (Oyem and Oyem, 2013) couple with access to air and water by the seeds might have accounted for the high germination rate in the combined (sawdust and detergent) and sawdust treatments, respectively.

The low germination rates in the $20 \mathrm{~g}$ detergent treatment and control suggest the toxicity of detergent and crude oil to germination of okra. Detergent contains chemicals such as bleach and chlorine with high pH (Chan, 2015) that may be detrimental to seed germination. Delays and decreases in the rate of seed germination in crude oil contaminated soil have been reported by Onuh et al. (2008) and Oyedeji et al. (2012).

Plant vegetative parameters of okra such as shoot length, leaf area, leaf number, leaf area ratio, fresh and dry biomass were affected by the amendment treatments when compared to the control; an indication that crude oil affect plant growth (Agbogidi et al. 2007; Tanee and Anyanwu, 2007; Kelechi et al., 2008; Eze et al., 2013). Significant improvements in these parameters were recorded in the amended treatments than the control. This may be attributed to the reduction in the THC content in addition to nutrient enrichment (especially the sawdust) of the amended soil. Thus the toxicity of crude oil to plant growth was drastically reduced in the amended soil.

It was vividly observed that the vegetative growth performance of okra in amended treatments was better in combination (20 g detergent $+200 \mathrm{~g}$ sawdust treatment) than when used in single (separate) form. This reveals that mixture of organic and chemical treatments is favourable in shielding and reducing the adverse effect of oil pollution to plants. This assertion is justifiable since there was above $70 \%$ reduction of THC in the combined treatment option. Also the enhancement of the soil chemical properties such as soil aeration, soil moisture content and $\mathrm{pH}$ in a crude oil polluted amended soil (Ikhajiagbe and Anoliefo, 2010) could have also contribute to the improved vegetative parameters of the okra. It is possible that in the combined treatment, the sawdust as an organic material with high nutrient content may have cushion the adverse effect of the detergent such as high pH (Chan, 2015) leading to favourable soil conditions for plant growth.

It is also possible that the low carbon content due to hydrocarbon degradation may have contributed to nutrient source to the plant for the stimulation of growth (Li et al., 1990). Improved vegetative yield of plants in crude oil remediated soil has been reported by Tanee and Albert (2011), Jonathan et al. (2013), Ayolagha and Peter (2013), Okon and Mbong (2013), Benson and Tanee (2016), and Jude and Tanee (2017).

\section{Conclusion}

This study reveals the effect of detergent and sawdust (either single or combine applications) as biostimulating agents for the degradation of petroleum hydrocarbons in soils as confirmed by the significant reductions in Total Hydrocarbon Content (THC) with improvement in vegetative growth of okra. It was observed that sawdust has higher biostimulation effect in petroleum contaminated soil with improvement in okra growth than detergent.

Highest performance was recorded in the combined treatment of sawdust and detergent than the single treatment options. Hence, sawdust is a prefer remediation option in crude oil polluted soil than detergent but better result can be obtained in the combined treatment than single treatment for the growth of okra.

\section{References}

Abosede, E.E. (2013). Effect of crude oil pollution on some soil physical properties. J. Agric \& Vet. Sc., 6(3): 14-17.

Abowei, M.F.N. (1996). Prediction and consequences of petroleum spills into the Nigerian aquatic environment in the year 2000. Int J. Environ. Pollut. 6: 306-316.

Akujobi, C.O., Onyeagba, R.A., Nwaugo, V.O. and Odu, N.N. (2011). Effect of nutrient amendment of diesel oil polluted soil on plant growth parameters. Cur. Res. J. Biol. Sci., 3(4): 421 - 429.

Agbogidi, O.M., Eruotor, P.G. and Akparabi, S.O.(2007). Effects of time of application of crude oil to soil on the growth of maize (Zea mays L.). Res. J. Environ. Toxicol. 1(3): 116-123.

Ajolagba, G.A. and Peter, K.D. (2013). Effect of remediation on growth parameters, grains and dry matter yield of soybean (Glycine max) in crude oil polluted ultisols in Ogoni land, south-east, Nigeria. Afri. J. Environ. Sci. Technol., 7(2): 61-67.

Akonye, L.A. and Onwudiwe, I.O. (2004). Potential for Sawdust and Chromolaena leaves as soil amendments for plants growth in oil polluted soil. Niger Delta Biologia, 4:50-60.

American Public Health Association (APHA), (1995). A Manual on Soxhlet Ext.APHA 5520D

Ambituuni, A., Amezaga, J., and Emeseh, E. (2014). Analysis of safety and environmental regulations for downstream petroleum industry operations in Nigeria: Problems and prospects. Environ. Devt., 9: 43-60

Anyanwu, D.I. and Tanee, F.B.G. (2008). Tolerance of 
cassava (var. TMS 30572) to different concentrations of post-planting crude oil pollution. Nig. J. Bot. 21(1): 203207.

Anyanwu, D.I., Awi-Waadu, G.D.B., Tanee, F.B.G. and Ochekwu, E.B. (2014). Fundamental Principles of Ecology. M \& J Grand Orbit Communications Ltd., Port Harcourt.

Asoegwu, S.N. (1988). Estimation of leaf area of two okra (Abelmoschus esculentus) varieties through leaf characteristics. Ind. J. Agric. Sci., 58(11): 862- 866.

Balasubramaniam, A., Boyle, A.R. and Voulvoulis, N. (2007). Improving petroleum contaminated and remediation decision making through the MCA weighting process. Chemosphere, 66: 791-798.

Benson D.M. and Tanee, F.B.G. (2016). Vegetative parameters and chlorophyll contents of okra (Abelmoschus esculentus L.) and Melon (Citrulus colocynthis, L.) in a crude oil polluted soil amended with cowdung and hydrogen peroxide. J. Global Agric. Ecol., 5(2): 92-100.

Boodoosingh, R., Swan, C., Desmarais, A.M. and Beckles, D.M. (2007). The effect of bulking agent and initial contaminant concentration on the biodegradation of total petroleum hydrocarbons. Proc. of the Annual International Conference on Soils, Sediments, Water and Energy 12: Article 23.

Chan, S. (2015). Hard water - is it affecting your plants' growth. www.growingnorth.ca/2015/hardwater-is-itaffecting-your-plants-growth. Accessed 8th Nov. 2016.

Chekroun, K.B.; Sánchez, E. and Baghour, M. (2014). The role of algae in bioremediation of organic pollutants. Int. Res. J. Public Environ. Health 1 (2): 19-32

Couto, M. N., Monteiro, E. and Vasconcelos, M.T. S. D., (2010). Microcosm trials of bioremediation of contaminated soil of a petroleum refinery: comparison of natural attenuation, biostimulation and bioaugmentation. Environ. Sci. Pollut. Res. 17: 1339 1346.

Dacko, M., and Dacko, A. (2009). Management of the Natural Environment-A Systemic Approach. Polish J. Environ. Studies, 18(2), 145-150.

Das, N., and Chandran, P. (2010). Microbial degradation of petroleum hydrocarbon contaminants: an overview. Biotech Res. Int.,
2010. (2011): 1-13.

Essien, O. E., and John, I. A. (2010). Impact of Crude-Oil Spillage Pollution and Chemical Remediation on Agricultural Soil Properties and Crop Growth. J Appl. Sci. Environ Mgt., 14 (4): 147-154.

Evelyn, M. I., and Tyav, T. T. (2013). Environmental pollution in Nigeria: The need for awareness creation for sustainable development. J. Res. Forest., Wildlife Environ., 4(2), 92-105.

Euliss, K., Ho, C., Schwab, A. P., Rock, S. and Banks, M. K. (2008). Greenhouse and field assessment of phytoremediation for petroleum contaminants in a riparian zone. Bioresource Technol, 99:1961-1971.

Eze, C.N., Maduka, J.N., Ogbonna, J.C. and Eze, E.A. (2013). Effects of Bonny-light crude oil contamination on the germination, shoot growth and rhizobacterial flora of Vigna unguiculata and Arachis hypogea grown in sandy-loam soil. Sci Res. Essays, 8(2): 99-107.

Gighi, J.G. Tanee, F.B.G. and Albert, E (2012). Postimpact assessment of crude oil spill site in Kpean community in Khana LGA (Ogoni) of Rivers State. J. Sci., 2(2): $109-120$.

Goodwin, N.; Nelson, J. A., Ackerman, F. and Weisskop, T. (2008). Economics in context: Goals, issues, a n d behavior. www.ase.tufts.edu/.../Economics_in_context... Retrieved December, 15, 2008.

Ikhajiagbe, B. and Anoliefo, G.O. (2010). Impact of soil amendment on phytotoxicity of a 5-month old waste engine oil polluted soil. J. Ecol. Nat. Environ., 2(6): 112122.

Jonathan, S.G. Oyetunji, O.J. Olawuji, O.J. and Uwukhor, P.O. (2013). Application of Pleurotus ostratus SMC as soil conditioner for the growth of soybean (Glycine max). Academia Arena, 5(1): 55- 61.

Jude, K and Tanee, F.B.G. (2016a). Efficacy of Chemical and Organic Remediation on Hydrocarbon Reduction and Growth Performance of Maize in a Crude Oil Contaminated Soil. Biotechnology Society of Nigeria $29^{\text {th }}$ Annual Conference held at University of Calabar from $28^{\text {th }}-31^{\text {st }}$ August, 2016.

Jude K and Tanee, F.B.G (2016b). Remediation Trials of Crude Oil Contaminated Soil using different sawdust and detergent Combination levels. Scientia Africana, 15 (2): 112-124.

Kelechi, L, Njoku, M.O.A. and Bola, O. (2008) Growth and Performance of Glycine max L. (Merrill) grown in 
crude oil contaminated soil augmented with cow dung. Nature and Science, 6(1): 20-30.

Kibblewhite, M. G., Ritz, K., and Swift, M. J. (2008). Soil health in agricultural systems. Philosophical Transactions of the Royal Society of London B: Biological Sciences, 363(1): 685-701.

Kumar, A., Bisht, B. S., Joshi, V. D. and Dhewa, T. (2011). Review on Bioremediation of Polluted Environment: A Management Tool. Int. J. Environ. Sci, 1(6): 1079- 1080.

Kumar, B. L. and Gopal, D. S. (2015). Effective role of indigenous microorganisms for sustainable environment. 3 Biotech., 5(6), 867-876.

Li, Y. Morris, J.T. and Yoch, D.C. (1990). Chronic low level hydrogen amendments stimulate plant growth and microbial activity in salt marsh microcosms. J. Appl. Ecol., 27: 159-171.

Liste, H.H, and Felgentreu, D. ( 2006). Crop growth, culturable bacteria, and degradation of petroleum hydrocarbons (PHCs) in a long-term contaminated field soil. Appl. Soil Ecol., 31: 43-52

Martínez-Jerónimo F.; Cruz-Cisneros J.L and García-Hernández, L. (2008). A comparison of the response of Simocephalus mixtus (Cladocera) and Daphnia magna to contaminated freshwater sediments. Ecotoxicol. Environ. Saf., 71:26-31.

Millioli, V. S., Servulo, E. L. C., Sobral, L. G. S. and De Carvalho (2009). "Bioremediation of Crude OilBearing Soil: Evaluating the Effect of Rhamnolipid Addition to Soil toxicity and Crude Oil Biodegradation Efficiency. Global Nest J., 11(2): 181-188.

Ogbo, E.M. (2009). Effect of diesel fuel contamination on seed germination of four crops plants - Arachis hypogea, Vigna unguiculata, Sorghum bicolor and Zea mays. Afri. J. Biotech., 8(2):250-253.

Okoh, A.I., (2006). Biodegradation alternative in the cleanup of petroleum hydrocarbon pollutants. A review. Biotech. Mol. Biol. 1(2):38-50.

Okon, J.E. and Mbong, E.O. (2013). Effect of nutrient amendments of spent engine oil polluted soil on some growth parameters of Abelmoschus esculentus (L) Moench in South-south Nigeria. Bull. Env. Pharmacol. Life Sci., 2(5): 75-78.

Onuh, M. O., Ohazurike, N. C. and Maduekwe, D. K.
(2008). Interaction of crude oil and manure treatments and its effects on the agronomic characteristics of maize (Zea mays, L.). Sci. World J. 3(2): 107-111.

Oyedeji, A.A., Adebiyi, A.O., Omotoyinbo, M.A. and Ogunkunle, C.O. (2012). Effect of crude oil contaminated soil on germination and growth performance of Abesmoschus esculentus L. Moench - a widely cultivated vegetable crop in Nigeria. Amer. J. Plant Sci., 3: 1451- 1454.

Oyem, I.L.R. and Oyem, I.L. (2013). Effects of crude oil spillage on soil physic-chemical properties in Ugborodo Community. Int. J. Modern Eng Res., 3(6): 3336-3342.

Pala, D.M., de Souza, J.A., de Carvalho, D.D. and Sant' Anna Jr, G.L.,( 2005). Effect of bulking agents and clay content on bioremediation of diesel-contaminated soils. Mercosur Con. Proc. Syst. Eng., 5: 1-10.

Tanee, F.B.G. and Anyanwu D.I. (2007). Comparative studies of the growth and yield of two cassava lines (TMS 30572 \& TMS 30555) in a crude oil polluted habitat. Scientia Africana 6(1): 81-84.

Tanee, F.B.G. and Albert, E. (2011). Biostimulation potential of sawdust on soil parameters and cassava (Manihot esculenta; Crantz) yields in crude oil polluted tropical soil. Adv. Environ. Biol., 5(5): 938 -945.

Tanee, F. B. G. and Albert, E. (2015). Reconnaissance Assessment of Long-Term Effects of Crude Oil Spill on Soil Chemical Properties and Plant Composition at Kwawa, Ogoni, J. Environ. Sci. Technol., 8(6), 320 -329.

Tanee, F.B.G. and Jude, K. (2017). Microcosm Trial of the use of detergent for Mitigation of Crude Oil Toxicity for Optimal Growth of Maize (Zea mays, L.). J. Appl Sci. Environ. Mgt., 21(1): 18 -28.

Thieman,W.J. and Palladino, M.A. (2009). Introduction to Biotechnology, 2nd edition. Pearson, New York.

Trejo-Hernandez, M.R., Ortiz, A., Okoh, A.I., Morales, D. and Quintero, R. (2006). Biodegradation of heavy crude oil Maya using spent compost and sugar cane bagas wastes. Chemosphere, 68: 848-855.

Wang XY, Feng J. and Zhao J M. (2010). Effects of crude oil residuals on soil chemical properties in oil sites, Momoge Wetland, China. Environ. Monit. Assess., 161: 271-280.

Wilcox, R. I. (2013). A review of the environmental effect of non renewable resources in Nigeria. Int. J. Soc. Sci. Hum. Rev., 4(2): 255-262. 
Zhu K, Chen H, Nan Z. (2010). Phytoremediation of loess soil contaminated by organic compounds. In: Kulakow P. A., Pidlisnyuk V. V. (eds) Application of Phytotechnologies for Cleanup of Industrial, Agricultural, and wastewater Contamination. NATO Science for Peace and Security Series C: Evironnental Security. Springer, Dordrecht. Pp.159-176. 